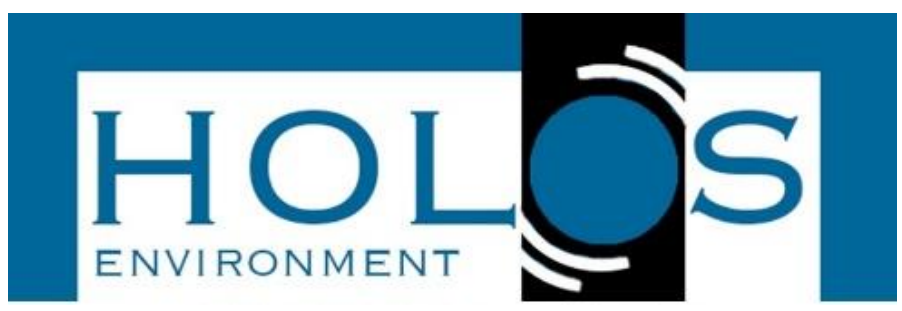

\title{
RESERVATÓRIOS COM PAREDE EM AÇO VITRIFICADO PARA REDUÇÃO DE PERDAS DE ÁGUA TRATADA
}

\section{VITRIFIED STEEL WALL RESERVOIRS FOR REDUCING THE LOSS OF TREATED WATER}

\author{
Thalyse Ungericht ${ }^{1}$; Elfride Anrain Lindner ${ }^{2}$
}

Artigo recebido em: 13/06/2019 e aceito para publicação em: 12/12/2019. DOI: http://dx.doi.org/10.14295/holos.v20i1.12348

\begin{abstract}
Resumo: As perdas de água tratada em reservatórios deve ser contida, pois resulta em água não faturada para as concessionárias. O processo de vitrificação, desenvolvido para ser aplicado em ambos os lados das chapas de aço, proporciona estanqueidade. $O$ aço estrutural recebe um esmalte de vidro fundido a 850 graus Celsius, camada inorgânica que nunca precisa de pintura e mantém suas características originais depois de mais de 60 anos de serviço. Este artigo visa apresentar o uso de chapas metálicas de aço vitrificado, na construção de reservatórios para armazenamento de água potável e comparar com os tradicionais construídos em concreto armado. A pesquisa incluiu identificação das normas técnicas internacionais, consulta as empresas executoras de reservatórios para armazenamento de água utilizando dois tipos de matérias (placas em aço vitrificado e concreto armado) e estudo de caso do uso dos reservatórios. As placas em aço vitrificado são fabricadas no exterior. Os representantes no Brasil fazem a importação e oferecem assistência técnica e mão de obra especializada. A autarquia Simae Joaçaba detém o primeiro reservatório de aço vitrificado que entrou em operação no Brasil no ano de 2007 (capacidade de $1.147 \mathrm{~m}^{3}$ ) e conta com sete reservatórios, com capacidade total de $6.797 \mathrm{~m}^{3}$, com esta tecnologia, ano de 2018 . Foram vistoriados reservatórios em concreto armado e em aço vitrificado em Joaçaba, com registro fotográfico, identificação de patologias no concreto e analise de vantagens e desvantagens entre os materiais. Os usuários entrevistados aprovam a utilização do aço vitrificado nos reservatórios para armazenamento de água potável, pela redução das perdas de água, melhor e mais eficiente limpeza, contribuindo para a qualidade da água.
\end{abstract}

Palavras-chave: Água tratada. Reservatórios. Aço vitrificado. Concreto armado.

\begin{abstract}
The losses of treated water in reservoirs must be contained, as it results in unbilled water for the concessionaires. The vitrification process is applied on both sides of the steel sheets, provides tightness. Structural steel receives a glass enamel melted at 850 degrees Celsius, an inorganic layer that never needs painting and retains its original characteristics after more than 60 years of service. This article aims to present the use of vitrified steel metal sheets in the construction of reservoirs for potable water storage and to compare with traditional ones constructed of reinforced concrete. The research included identification of international technical standards, consultation of companies executing reservoirs for water storage using two types of materials (vitrified steel plates and reinforced concrete) and case study of the use of reservoirs. Glazed steel plates are manufactured outside. The representatives in Brazil do the import and offer technical assistance and specialized labor. The Simae Joaçaba holds the first vitrified steel reservoir that came into operation in Brazil in $2007\left(1,147 \mathrm{~m}^{3}\right.$ capacity) and has seven reservoirs, with a total capacity of $6,797 \mathrm{~m}^{3}$, with this technology, in 2018. They were surveyed reservoirs in reinforced concrete and vitrified steel in Joaçaba, with photographic registry, identification of pathologies in the concrete and analysis of advantages and disadvantages between the materials. The users interviewed approve the use of vitrified steel in the reservoirs for potable water storage, by reducing water losses, better and more efficient cleaning, contributing to water quality.
\end{abstract}

\footnotetext{
${ }^{1}$ PortalSeg - Segurança e Saúde do Trabalho, Catanduvas - SC. E-mail: (thalyseu@hotmail.com)

${ }^{1}$ Universidade do Oeste de Santa Catarina (UNOESC), Joaçaba, SC. E-mail: (elfride.lindner@unoesc.edu.br)
} 
Keywords: Treated water. Reservoirs. Vitrified steel. Reinforced concrete.

\title{
1 INTRODUÇÃO
}

No setor de saneamento um dos principais indicadores de eficiência da operação dos sistemas de abastecimento de água é o índice de perdas. Com valores médios que beiram os $40 \%$, as perdas reais são divididas em perdas na tubulação de água bruta e vazamento nos reservatórios, redes e ramais. $O$ combate às perdas de água é um grande desafio dos operadores brasileiros públicos e privados, segundo a Associação Brasileira de Engenharia Sanitária e Ambiental - ABES (2013).

A International Water Association - IWA (2006, apud ALMEIDA et al., 2018) no quadro do Balanço Hídrico, destaca entre as perdas reais (físicas) os "vazamentos e extravazamento nos reservatórios (de adução e /ou distribuição", que resultam em água não faturada.

Almeida (2006) na disciplina de "Água em Ambientes Urbanos" discorre sobre o controle e redução de perdas reais em sistemas de abastecimento de água. No item Vazamentos em Reservatórios, manifesta-se:

\begin{abstract}
Os vazamentos não-visíveis em reservatórios ocorrem nos pontos fragilizados da estrutura, geralmente devido a trincas na base do reservatório e imperfeições na ligação com as tubulações da adutora. A água é drenada pelo próprio sistema de drenagem abaixo do reservatório e, portanto, não aflora.

Para detecção destes vazamentos realiza-se o teste de estanqueidade [...] com equipamentos especiais, como infravermelhos, ou manualmente, fechando-se totalmente as válvulas de entrada e saída do reservatório e registrando-se a variação de nível no período determinado. O reparo deve ser feito assim que detectado o vazamento, revestindo-se novamente toda a estrutura se necessário. Quando o reservatório utilizado é metálico, medidas para evitar a corrosão são necessárias, como proteção catódica e pinturas especiais (ALMEIDA, 2006).
\end{abstract}

A adoção de novas tecnologias em reservatórios de água tratada é importante, com uso de novos materiais para a diminuição de desperdício de água e manutenções. A citar, os reservatórios em paredes de aço vitrificado que vêm em substituição aos reservatórios de concreto ou aço soldado.

Os reservatórios em paredes de placa de aço vitrificado vêm ganhando ainda mais espaço, como uma solução no mercado, pela crescente necessidade de otimização das obras, seja decorrente de restrições orçamentárias ou ainda do prazo curto para sua execução (BACARIN et al., 2017)

Os reservatórios em paredes de chapas de aço vitrificado evoluíram da solução das chapas soldadas em campo para a montagem parafusada (BACARIN et al., 2017).

Medeiros Filho (2009) define que os reservatórios de água são unidades hidráulicas de acumulação e passagem de água situados em pontos estratégicos do sistema, visando a garantia da quantidade de água e de adução com vazão e altura manométrica constantes; menores dâmetros no sistema e melhores condições de pressão.

Torres, da Silva e Paliga (2016) descrevem reservatório de água como um monumento de ferro construído em 1871 com a técnica de pré-fabricação em peças 
metálicas. Com o surgimento de novas tecnologias, foram projetados elementos em concreto armado. O concreto armado é um material que, sob efeito de intempéries e sem manutenção periódica pode sofrer degradação.

De acordo com a Eurotanks (2014) reservatórios com chapas de aço vitrificado mantêm suas características originais por mais de 60 anos de serviço. $O$ revestimento das chapas de aço é obtido quando o aço estrutural recebe um esmalte de vidro fundido a 850 graus Celsius, camada inorgânica que nunca precisa de pintura e mantém suas características originais depois de mais de 60 anos de serviço. O material tem a resistência e flexibilidade do aço com a resistência à corrosão do vidro, sem a habitual fragilidade do vidro. Isto, porque, como o aço esfria após a fusão com o vidro este é aplicado e permanece sob compressão mesmo quando existe a dobra de aço decorrente da curvatura da chapa.

A qualidade é decorrente de rigoroso controle no processo fabril das chapas e do revestimento vitrificado, além de ampla variedade de capacidades disponíveis e gama de aplicações. Propiciam uma montagem rápida e limpa sem necessidade de equipamento pesado, equipamentos para soldas, soldadores, testes de raio $\mathrm{X}$, ultrassom, líquido penetrante, entre outros (TARGET, 2015).

O fato de o reservatório já vir pronto da fábrica, segundo Bacarin et al. (2017) leva a uma menor mobilização de mão de obra no canteiro, menor prazo de execução da obra, menor necessidade de espaço no canteiro de obra, diminuição do consumo de recursos naturais e menor geração de resíduos de obra.

Tipicamente executado num sistema em que a base é de concreto, assentando-se sobre fundação direta ou indireta, as chapas parafusadas são fáceis de montar e praticamente não necessitam de manutenção (BACARIN et al., 2017).

Os tanques vitrificados podem ser desmontados e instalados em outro local, investindo apenas na construção de uma nova base de concreto. Para expandir a capacidade de armazenamento, basta elevar a altura do reservatório instalando novos painéis de aço (TARGET, 2015).

O menor risco aos vazamentos é justificado pela estanqueidade do reservatório ser realizada pela aplicação de um selante mastique entre as chapas, ou através de juntas préfabricadas nas dimensões do reservatório (METALTEC, 2015).

A facilidade na higienização e manutenção simplificada e de baixo custo é justificado por Bacarin e outros (2017) que afirmam que o vidro está quimicamente e mecanicamente fundido ao aço e não requer manutenção periódica ou retoques de pintura durante sua vida útil.

Na presente revisão bibliográfica são mostradas as características do aço vitrificado e comparadas com outros materiais utilizados para construção de reservatórios de água tratada. Com os dados do estudo de caso da utilização dos reservatórios de água potável, com parede em placas de aço vitrificado no Serviço Intermunicipal de Água e Esgoto Simae de Joaçaba - SC são apresentados os resultados da utilização desses reservatórios com suas vantagens e desvantagens. 


\section{MATERIAIS E MÉTODOS}

Foram consultados sites, prospectos de empresas fabricantes e contatados representantes de empresas fabricantes para avaliar o uso de materiais construtivos, com ênfase em chapas de aço vitrificado em reservatórios de água potável. Através de sites que divulgam a tecnologia, usando o recurso "fale conosco", foram enviadas perguntas para empresas que divulgam informações comerciais na web.

O estudo de caso no Simae de Joaçaba - Santa Catarina contou com um questionário elaborado pela autora, sobre reservatórios de água potável construídos em paredes de placas de aço vitrificado, respondido pelo setor técnico da autarquia. $\mathrm{O}$ questionário foi enviado via correio eletrônico e esclarecido pessoalmente durante visita.

Foram realizadas visitas in loco nos reservatórios do Simae nos municípios de Joaçaba e Luzerna, para registro fotográfico, com uso de um Iphone 7.

A análise dos dados consistiu na tabulação das respostas colhidas em questionário e conversa pessoal. As tecnologias para a construção de reservatórios de água potável (concreto armado; placas de aço com revestimento vitrificado) foram contempladas na análise.

\section{RESULTADOS E DISCUSSÃO}

\subsection{Instalação de reservatórios de água potável em placas de aço vitrificado}

Nove empresas que divulgam a comercialização de reservatórios de água potável no Brasil, foram consultadas através de perguntas comuns, em contato via correio eletrônico. Dentre elas, três responderam o questionário.

A empresa Tech Tank com sede no Brasil em Saltinho, São Paulo, através do setor de vendas, via contato eletrônico, disponibilizou um arquivo com a sequência de instalação de um reservatório em aço vitrificado com capacidade de $25.000 \mathrm{~m}^{3}$, de dimensões de 57 $\mathrm{m} \times 14 \mathrm{~m}$, montado na cidade de Barranquilla, Colômbia.

A sequência está apresentada na Figura 1.

Em 1 a) vê-se os trabalhadores realizando a montagem da armadura da base em concreto armado. Com a base concluída, inicia-se a instalação do anel superior e após, a do esqueleto da cobertura em forma de cúpula geodésica, construída em alumínio (1 b)). Em 1 c) e 1 d) é visto o fechamento da cobertura com telhas metálicas.

A montagem das placas em aço vitrificado do costado no reservatório (1 e) faz uso de macacos hidráulicos para suspender as placas superiores e agregar as novas peças. A instalação dos acessórios para o reservatório conta com auxílio de um guincho (1f).

A Figura 2 mostra o reservatório concluído. 
Figura 1 - Etapas da construção do reservatório de água potável em aço vitrificado

a) Preparação da base de concreto

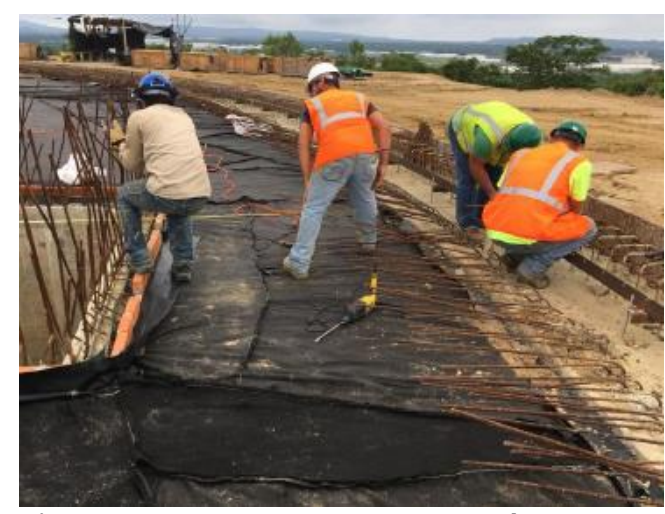

c) Instalação do esqueleto da cúpula geodésica de alumínio

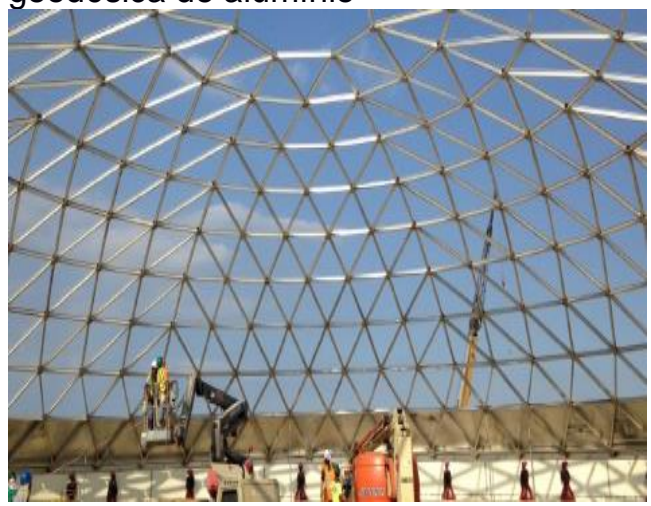

e) Instalação do corpo do tanque, vista interna

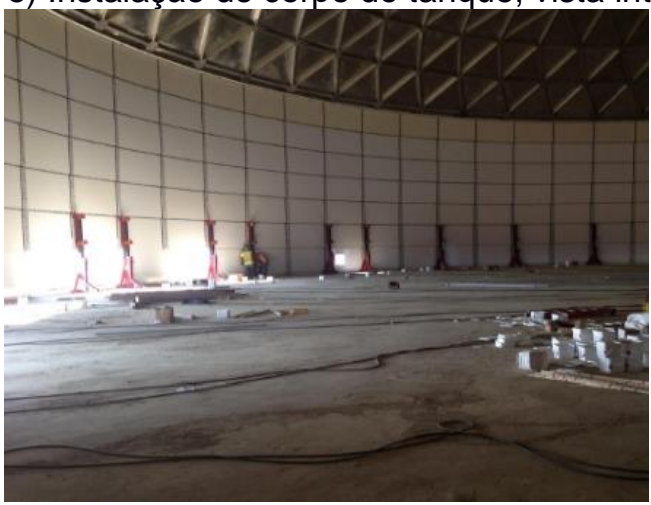

f) Colocação de peças e acessórios

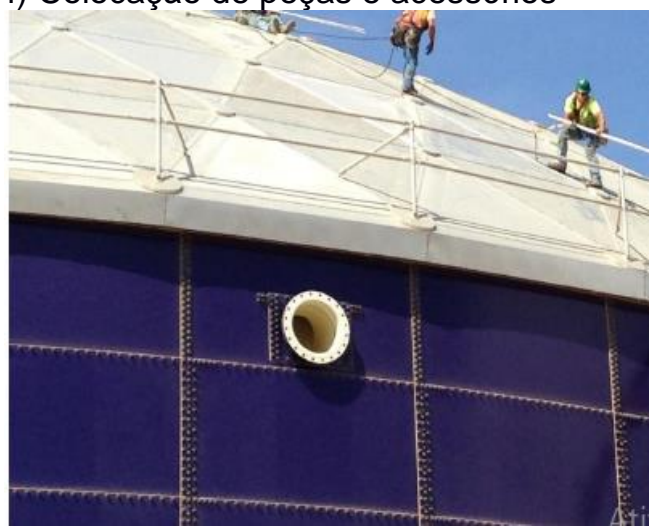

Fonte: Tech Tank (2016). b) Instalação do anel superior e do esqueleto da cúpula geodésica

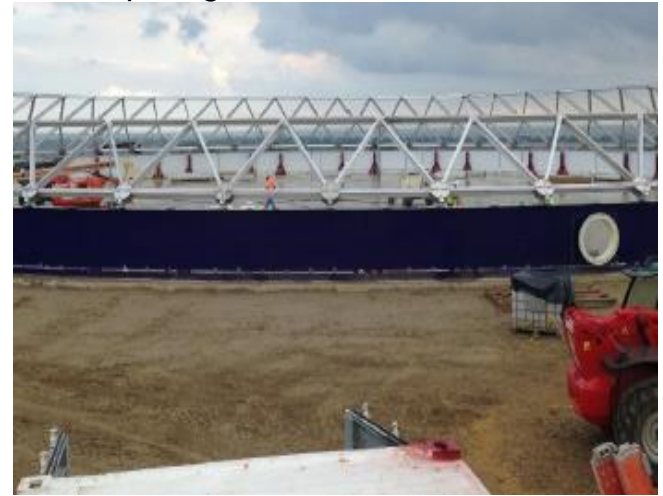

d) Cobertura do esqueleto da cúpula geodésica, vista interna

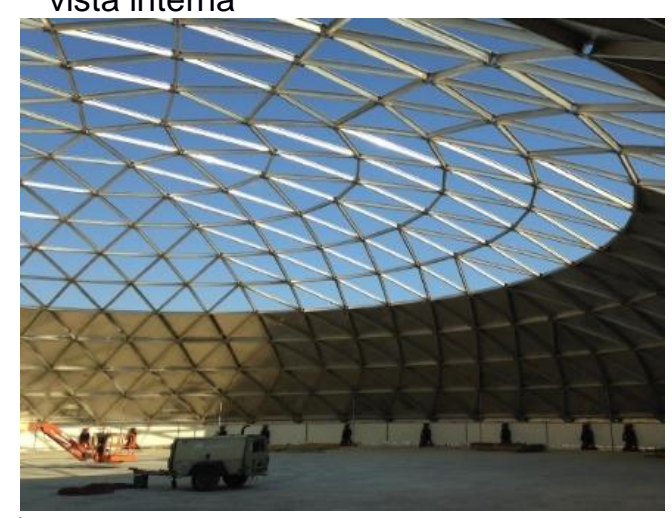

e) Instalação do corpo do tanque, vista externa
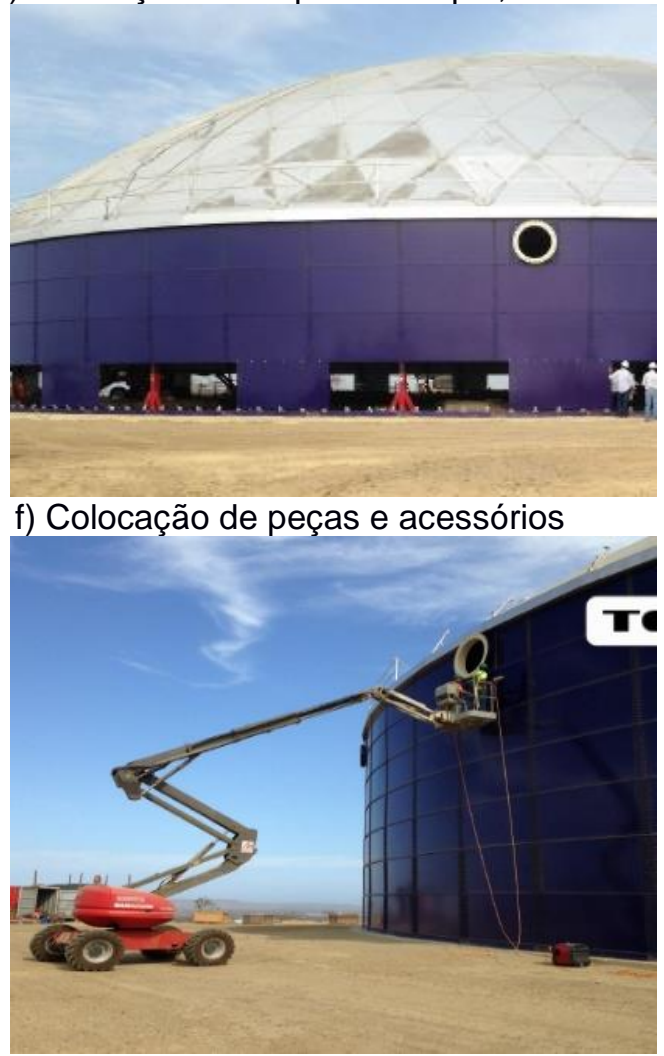
Figura 2 - Reservatório de água potável em aço vitrificado concluído

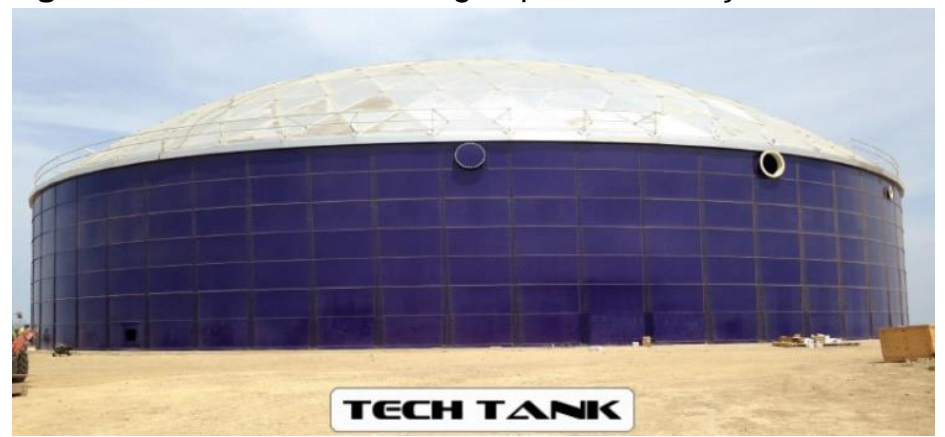

Fonte: Tech Tank (2016)

Em contato via correio eletrônico com a empresa Metaltec Engenharia Ltda., de Florianópolis, foi recebida informação, através do engenheiro mecânico Thiago Augusto Baudy, sobre o processo de vitrificação do aço, bem como, os procedimentos de montagem dos reservatórios de placas de aço vitrificado, constantes nas normas da International Organization for Standardization, ISO 28765:2016 Vitreous and porcelain enamels - Design of bolted steel tanks for the storage or treatment of water or municipal or industrial effluents and sludges e AWWA D103-09 Factory-Coated Bolted Carbon Steel Tanks for Water Storage (BAUDY, 2018). Como visto acima, a fabricação e instalação seguem normas internacionais.

\subsection{Uso de reservatórios em paredes de aço vitrificado no Brasil}

O uso de reservatórios em parede de aço vitrificado para armazenamento de água potável tem se expandido no Brasil a partir de 2009 (Tabela 1). Os reservatórios têm diferentes capacidades, sendo o maior com $10.000 \mathrm{~m}^{3}$, instalado para a concessionaria SANEPAR, o que mostra a versatilidade do uso de paredes de aço vitrificado.

Predomina o uso pelas concessionárias de água da região Sul (15 unidades) e Sudeste (6 reservatórios no estado de São Paulo). O estado de Santa Catarina aparece como o que mais aplica a tecnologia. A Tabela 1 não contempla os reservatórios do Simae Joaçaba, objeto da presente pesquisa de campo, com destaque posterior.

O Departamento de Água, Arroios e Esgoto de Bagé - Daeb do RS inaugurou reservatório feito de chapas de aço vitrificado, material vindo dos Estados Unidos, noticiando a tecnologia diferenciada em reservação de água tratada. A unidade tem capacidade de 4 milhões de litros, adquirido por $\mathrm{R} \$ 3.200 .409,40$, com recursos próprios de arrecadação de água (DAEB, 2019). 
Tabela 1 - Reservatórios de água potável em parede de aço vitrificado instalados no Brasil (2009-2018)

\begin{tabular}{llrrrr}
\hline Concessionária & Cidade - Estado & Ano & $\begin{array}{r}\text { Diâmetro } \\
(\mathbf{m})\end{array}$ & $\begin{array}{r}\text { Altura } \\
(\mathbf{m})\end{array}$ & $\begin{array}{r}\text { Capacidade } \\
\left(\mathbf{m}^{\mathbf{3}}\right)\end{array}$ \\
\hline CAJ & Joinville - SC & 2009 & - & - & 2.000 \\
\hline SABESP & São Bernardo do Campo - SP & 2010 & - & - & 4.000 \\
\hline SABESP & São Paulo - SP & 2010 & - & - & 3.000 \\
\hline CAJ & Joinville - SC & 2012 & 38,00 & 7,90 & 8.000 \\
\hline SEMAE & Brusque - SC & 2013 & - & - & 2.000 \\
\hline SEMAE & Campos Novos - SC & 2013 & - & - & 2.000 \\
\hline CASAN & Araquari - SC & 2015 & - & 15,00 & 2.000 \\
\hline SAAE & Marechal Cândido Rondon - PR & 2015 & 22,00 & 13,00 & 4.000 \\
\hline SAMAE & Araranguá - SC & 2016 & - & - & 1.500 \\
\hline CASAN & Florianópolis - SC & 2017 & 22,60 & 8,00 & 3.000 \\
\hline EMASA & Balneário Camboriú - SC & 2017 & - & - & 2.800 \\
\hline SAMAE & Blumenau - SC & 2017 & - & - & 5.000 \\
\hline SANASA & Campinas - SP & 2017 & - & - & 3.500 \\
\hline SANASA & Campinas - SP & 2017 & - & - & 2.500 \\
\hline SANASA & Campinas - SP & 2017 & - & - & 2.500 \\
\hline SANASA & Campinas - SP & 2017 & - & - & 2.000 \\
\hline SANEPAR & Cascavel - PR & 2017 & 11,33 & 6,50 & 660 \\
\hline SANEPAR & Curitiba- PR & 2007 & 40,00 & - & 10.000 \\
\hline AsCORSAN & Gramado - RS & 2018 & 26,44 & 9,65 & 3.000 \\
\hline DAEB & Bagé - RS & 2018 & 41,00 & 3,00 & 4.000 \\
\hline SAMAE & Caxias do Sul - RS & 2018 & - & - & 5.000 \\
\hline
\end{tabular}

\subsection{Estudo de caso no Simae de Joaçaba - SC}

O estudo de caso no Simae de Joaçaba - SC contou com o apoio do Diretor Presidente - Paulo Cesar Lamin, e do Diretor Técnico - André Francisco Fiorin.

Fotos da construção do primeiro reservatório com paredes em chapa de aço vitrificado na cidade de Joaçaba também foram cedidas pelo Diretor Técnico para utilização na presente pesquisa.

\subsubsection{Análise das respostas ao questionário aplicado ao Simae}

Em resposta ao questionário aplicado obtiveram-se as seguintes informações: Sobre a descoberta dos reservatórios metálicos em paredes de placas em aço vitrificado, o Simae afirma que a tecnologia de construção dos reservatórios em chapas de aço vitrificadas, foi descoberta e apresentada inicialmente a Sra. Elisabet Maria Zanela Sartori, Diretora Presidente do Simae da época, em um evento promovido pela ASSEMAE - Associação Nacional dos Serviços Municipais de Saneamento, realizada na cidade de Joinville - SC no ano de 2006.

Reservatórios metálicos em paredes de placas em aço vitrificado têm a Inglaterra como país de origem. No Brasil, ano de 2007, a tecnologia era novidade e não havia nenhum reservatório construído. Porém a empresa Permastore, que apresentou essa tecnologia ao Simae, iniciou as suas atividades em 1959 e já possuía inúmeros reservatórios espalhados por mais de 100 países. 
Quanto à fabricação dos reservatórios em chapas de aço vitrificado hoje no Brasil ou se ainda há necessidade de importação de alguma parte do processo, foi informado que as empresas brasileiras ainda importam as chapas de aço vitrificado dos reservatórios. Sabese da fabricação na Inglaterra, na Áustria e nos Estados Unidos, aumentando a oferta de empresas fornecedoras do produto.

O Simae realizou a primeira compra no Brasil do reservatório em paredes de placas de aço vitrificado através do processo de licitação no 2549/2006, Tomada de Preços 08/2006. Porém como especificado, os técnicos do Simae só conheciam um fornecedor da tecnologia de reservatório em chapa de aço vitrificado, e assim a licitação ficou aberta para participação de empresa que fabricassem reservatórios em chapa de aço soldada ou parafusada, com revestimento em vidro fundido ou pintura.

O Simae (ano 2006) foi a primeira concessionária na aquisição e a segunda na instalação desta tecnologia em reservatórios no Brasil. A Companhia de Saneamento do Paraná - Sanepar foi pioneira em Curitiba (ano 2007), porém a montagem dependeu de obras complementares para entrar em carga. O Reservatório Apoiado - RAP e com o número sequencial 2 (RAP002) do Simae - Joaçaba foi o primeiro reservatório com parede de aço vitrificado a entrar em operação no Brasil.

Antes da instalação do primeiro reservatório, seguindo as normas técnicas vigentes, na própria fábrica são realizados testes de: Medição da Cor; Medição da Espessura do Vidro; Inspeção do Revestimento; Ensaios de Resistência Química; Ensaios de Propriedades Físicas.

A instalação do primeiro reservatório não seguiu o cronograma estipulado no início da obra. O Simae cita contratempos como o atraso no transporte marítimo e a liberação por parte da Receita Federal do Brasil no porto.

A base do reservatório em paredes de placas em aço vitrificado é em concreto armado. Para a construção do primeiro reservatório esta base foi calculada por um engenheiro de Curitiba - Paraná, com experiência em obras de concreto. Já a execução foi realizada por uma equipe local de Joaçaba.

A montagem do reservatório (parede e teto), foi realizado por uma equipe técnica da Felchack, cujo chefe recebeu treinamento na Inglaterra. Por ser o primeiro reservatório a ser montado no Brasil, um técnico da Permastore, empresa fabricadora do reservatório, esteve em Joaçaba para supervisionar a montagem.

O Simae cita que o canteiro de obras tinha aspecto normal para obras que envolvem concreto armado da base. Para a montagem das paredes em aço vitrificado, foi utilizada uma empilhadeira que trabalhava sobre a base (piso) do reservatório, deixando a obra com aparência limpa e desimpedida.

O questionário permitiu o relato de possíveis problemas que ocorrem nos diversos reservatórios do Simae Joaçaba. No RAP 002, construído em 2007, apresentou um pequeno vazamento em uma das emendas de chapa, em 2009. O problema foi resolvido com a troca do selante e reaperto dos parafusos de fixação da chapa. A partir daí não apresentou mais nenhum problema.

Outro problema mencionado foi no RAP 019, construído em 2009, que apresentou vazamento em uma chapa no ano passado (2017). O vazamento foi contido com um aperto nos parafusos de fixação das chapas. 
Consultou-se o Simae se a água apresentou alguma alteração ao ser armazenada neste reservatório e se havia alguma contraindicação sobre o uso desses reservatórios com placas de aço vitrificado. Para essa pergunta, as respostas foram negativas.

Foi realizada a comparação do reservatório todo concreto armado com o reservatório em placas de aço vitrificado. Uma das perguntas foi para o Simae listar os benefícios, por tipo de material construtivo. Para o reservatório em placas de aço vitrificado, pela ordem, seguem as respostas: apresenta menor risco de vazamentos; a vida útil maior estimada em mais de 50 anos; facilidade na higienização, pois a sujeira adere menos ao vidro; manutenção simplificada, pois não precisa de recuperação estrutural e pinturas frequentes como os de concreto.

Já os reservatórios totalmente em concreto armado têm a seu favor o domínio da tecnologia por empresa brasileiras, facilidade de mão de obra para reparos não estruturais e pintura.

Quanto ao material construtivo, pela experiência do Simae, os reservatórios totalmente em concreto armado apresentam mais problemas. Referente à necessidade de manutenção, os reservatórios construídos em concreto armado exigem mais atenção e reparos no Simae.

Ao comparar as tecnologias conhecidas, o Simae destacou a mais benéfica, na análise geral. A resposta foi que são os reservatórios de aço vitrificado apresentam maiores benefícios.

Perguntou-se se houve uma pesquisa de comparação de valores entre as diferentes tecnologias para a construção do reservatório (concreto armado, reservatório metálico, reservatório em placas de aço vitrificado). O Simae respondeu que na primeira aquisição o edital foi liberado para construção de reservatório em chapas de aço soldadas e pintadas e para reservatórios em chapa de aço vitrificado. Na ocasião, apenas a empresa Felchack apresentou proposta com os reservatórios em chapa de aço vitrificado. As empresas fabricantes e reservatórios em chapas de aço soldadas na obra, alegaram que o valor orçado pelo Simae era muito baixo e que não tinham como fornecer seus reservatórios pelo preço máximo fixado na licitação.

As fotos da construção do primeiro reservatório em placas de aço vitrificado RAP002, disponibilizadas pelo Simae Joaçaba, são mostradas na Figura 3 e Figura 4.

O terreno sendo terraplanado com utilização de uma escavadeira de esteira é visto em 3 a). Após o preparo do terreno foi construído um barraco de obra para armazenamento dos materiais $(3 \mathrm{~b})$. A execução da base do reservatório em concreto armado, disposição das armaduras e após a base a concretagem da base, concluindo a obra é ilustrada em 3 c).

A montagem do costado do reservatorio em aço vitrificado, mostrada nas Figuras 3 d) e 3 e), com utilização de uma empilhadeira elétrica (Carmak ou similar), para a movimentação das placas de aço vitrificado. $O$ aperto dos parafusos é realizado por pessoas qualificadas com o uso de máquina manual, para total controle do valor do torque especificado em projeto, visto em $3 \mathrm{f}$ ). A cobertura utilizada neste reservatorio pelo Simae Joaçaba tem a forma plana, em estrutura de alumínio com telhas metálicas $(3 \mathrm{~g})$. A montagem dos acessórios como tubulação de entrada e saida da água com a utilização de um guincho para realizar a movimentação das peças é mostrada em $3 \mathrm{~h}$ ). 
Figura 3 - Construção do primeiro reservatório do Simae Joaçaba em paredes com placas de aço vitrificado

a) Terraplanagem do terreno

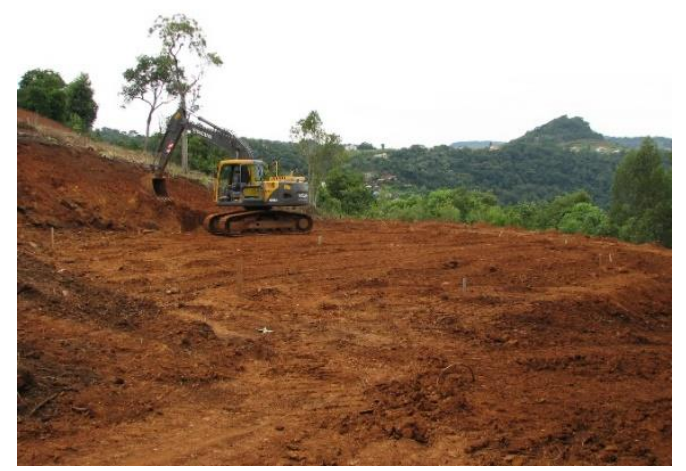

c) Base em concreto armado finalizada

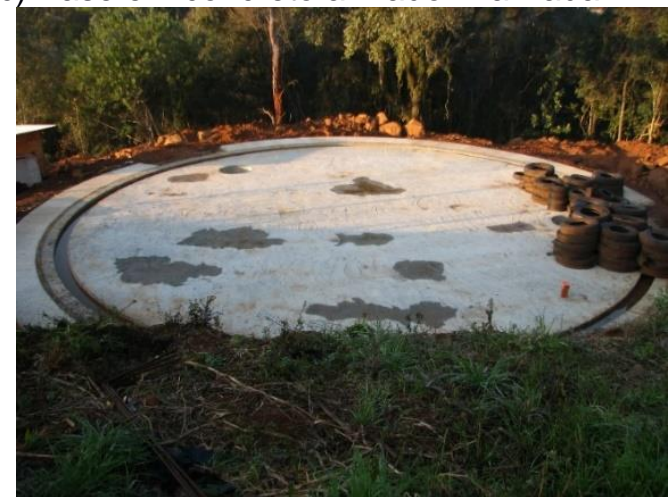

e) Montagem do costado com destaque da empilhadeira utilizada para movimentação das peças

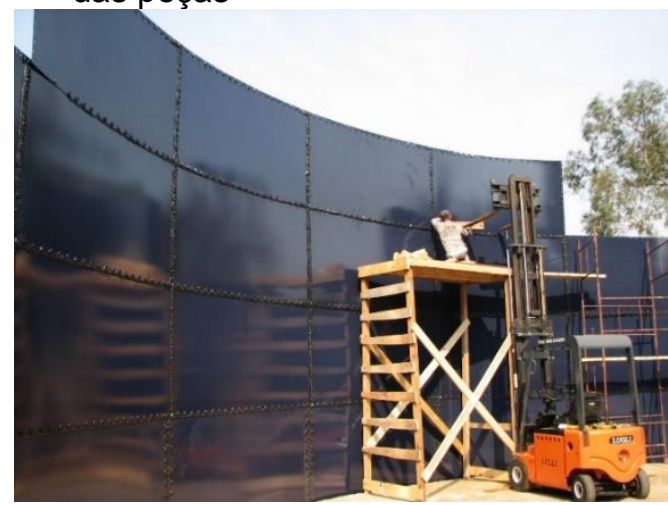

g) Estrutura de cobertura em alumínio concluída, fixação das telhadas metálicas

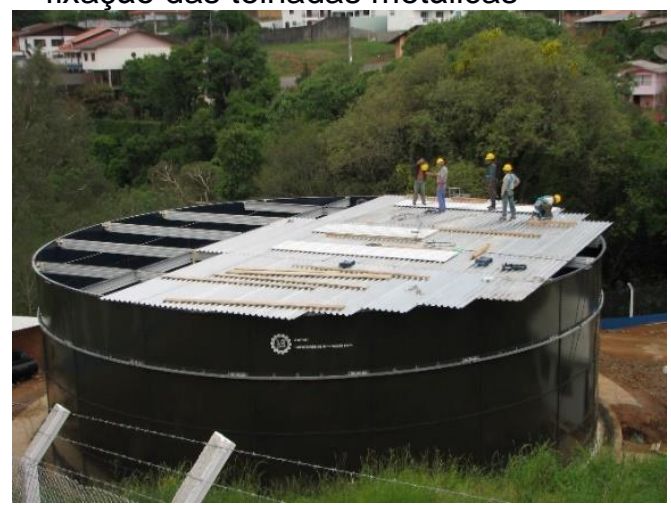

Fonte: Simae Joaçaba (2018). b) Instalação do canteiro de obra

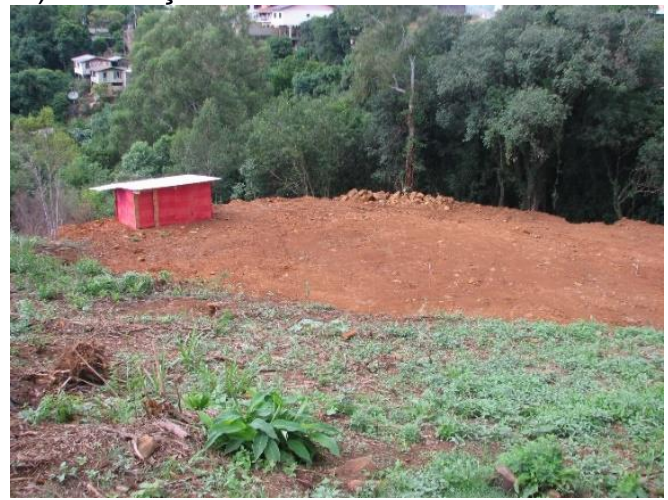

d) Inicio da montagem do costado

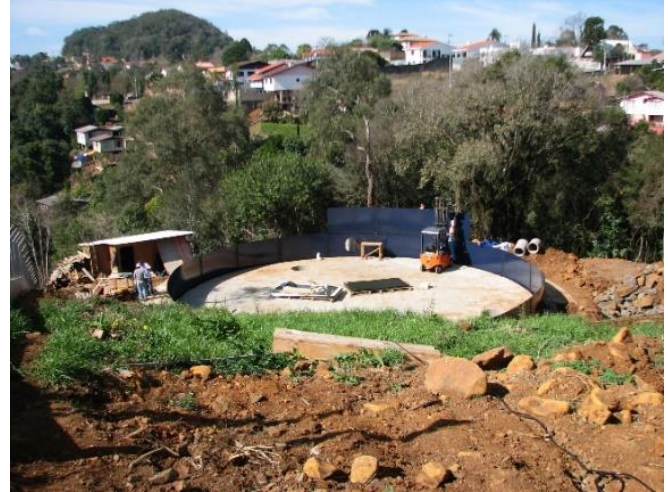

f) Fixação das placas com destaque para o controle do torque de aperto dos parafusos

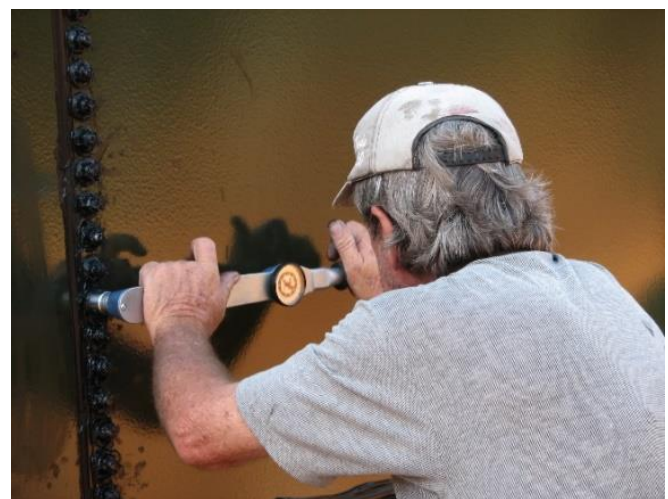

h) Montagem dos acessórios

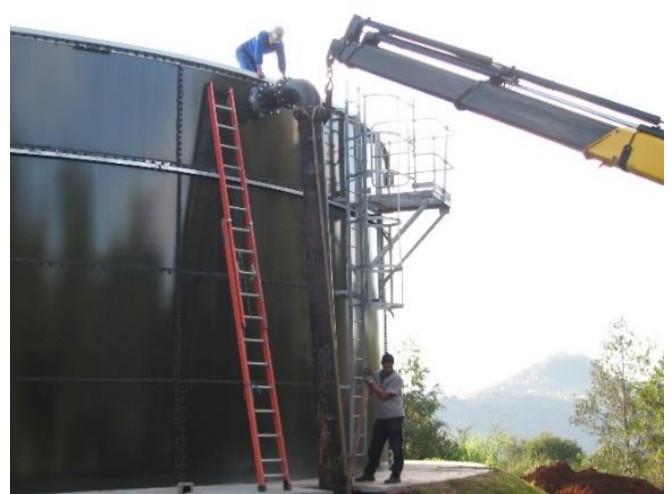


A Figura 4 apresenta o RAP002 concluído e em operação na cidade de Joaçaba SC.

Figura 4 - Reservatório RAP002 do Simae Joaçaba concluído e em operação

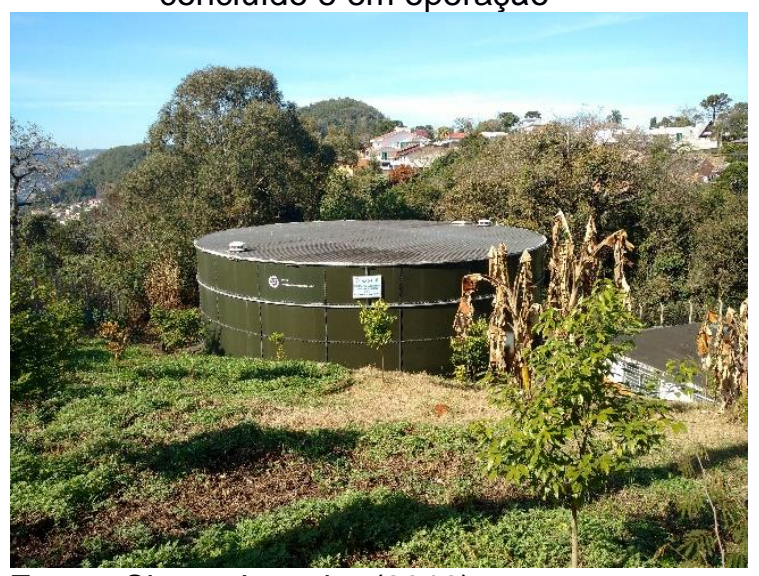

Fonte: Simae Joaçaba (2018).

Considera-se que as respostas dadas ficaram a contento, finalizando-se o estudo de caso de aplicação do questionário no Simae de Joaçaba.

Em conversa com o diretor técnico, foi repassado que o Simae Joaçaba - SC até o ano de 2018 possuia sete reservatórios em placas de aço vitrificado instalados nas três cidades de abrangência da autarquia, com volume total de $6.797 \mathrm{~m}^{3}$ de capacidade para armazenamento de água potável. A Tabela 2 complementa a Tabela 1, especificando os reservatórios em parede com placas de aço vitrificado do Simae Joaçaba. Observa-se o nome dos reservatórios, conforme denominação oficial do Simae com a sigla RAP, seguido de número identificador, com seus respectivos volumes de armazenamento de água potável.

Tabela 2 - Reservatórios em paredes de aço vitrificado em operação no Simae Joaçaba - SC

\begin{tabular}{lrrrrrrrr}
\hline Identificação & RAP002 & RAP0019 & RAP008 & RAP017 & RAP020 & RAP023 & RAP001 & Total \\
\hline Volume, $\mathbf{m}^{\mathbf{3}}$ & 1.147 & 2.000 & 500 & 250 & 500 & 500 & 1.900 & $\mathbf{6 . 7 9 7}$ \\
Ano & 2007 & 2009 & 2012 & 2012 & 2013 & 2013 & 2014 & \\
Localização & & Joaçaba & Luzerna & Joaçaba & Joaçaba & Joaçaba & & \\
& Joaçaba & & & & & & Joaçaba & \\
\hline
\end{tabular}

Fonte: Simae Joaçaba (2018)

\subsubsection{Reservatórios da Estação de Tratamento de Água do Simae Joaçaba}

A realização da visita in loco na Estação de Tratamento de Água - ETA foi acompanhada pelo setor técnico de engenharia do Simae Joaçaba - SC e pelo chefe responsável pela ETA.

Durante a realização da visita foram visualizados dois diferentes tipos de reservatórios: reservatório com uso de chapas de aço vitrificado com cobertura em chapas de alumínio no formato de cúpula geodésica e reservatório todo em concreto armado. 


\subsubsection{Reservatório em paredes de placas em aço vitrificado}

O reservatório em paredes de placas em aço vitrificado visitado tem por finalidade o armazenamento da água logo após o seu tratamento. Na Figura 5 e Figura 6 é possível observar o reservatório RAP 001B com seus detalhes.

A capacidade de reservação é de $1.900 \mathrm{~m}^{3}$, com diâmetro de 17,08 metros e altura de 8,59 metros. Para efeitos de cadastro, o Simae denomina este reservatório como RAP001B. Foi instalado no ano de 2014 e entrou em operação no mesmo ano.

As Figuras 5 a) e 5 b) Figura 5 a) e Figura 5 b) mostram vistas frontal e superior do reservatório RAP 001B. A placa de identificação do reservatório $(5 \mathrm{c})$, permite a rastreabilidade pelo fabricante - Permastore ${ }^{\circledR}$. $O$ selo de identificação do controle de qualidade, pela ISO, Fusion V700 é mostrado em $5 \mathrm{~d}$ ).

A quantidade de parafusos para fixar as chapas é maior nas chapas junto a base do que nas chapas junto ao teto, devido a pressão exercida pelo liquido (água) armazenada no interior do reservatório está exemplificada na Figura 5 e). Pode ser observada também a padronização da montagem, especificada no projeto de montagem a quantidade de parafusos necessária, onde as quatro primeiras chapas apresentam três linhas de parafusos e as duas últimas apenas um.

Na Figura 5 f) pode-se observar a instalação de perfis metálicos em aço galvanizado, que são fixados em forma de arco nas ultimas três junções das chapas, com finalidade de resistência à ação do vento.

Após a fixação das chapas e aperto dos parafusos no torque determinado em projeto, a parte aparente dos parafusos e a porca são cobertos com uma capa plástica com função estética (Figura 6 a).

a Figura 6 b), é possível ver a junção entre duas chapas onde a sobra do selante utilizado entre as placas recebeu um acabamento em chanfro. Também é possível observar um orifício quadrado, utilizado para movimentação da placa no processo de vitrificação.

$\mathrm{Na}$ Figura $6 \mathrm{c}$ ), observa-se a porta de limpeza com diâmetro de $800 \mathrm{~mm}$, superior ao mínimo recomendado de $600 \mathrm{~mm}$, que é instalada na primeira chapa junto a base, com objetivo de permitir o acesso de pessoas no interior do reservatório, para inspeções e manutenção/ limpeza do mesmo.

A escada tipo marinheiro, que pode ser observada na Figura 6 d), é utilizada para acesso a cobertura, onde através de abertura existente no teto é possível observar o interior do reservatório.

A cobertura do reservatório RAP001 ( Figura 6 e), foi executada em cúpula geodésica. O custo é maior do que a cobertura plana, mas valoriza o aspecto arquitetônico do reservatório. A inclinação é um quesito que não sido mostrado relevante na escolha, permitindo o uso de cobertura plana. 
Figura 5 - Reservatório RAP001 com placas em aço vitrificado do Simae Joaçaba

a) Reservatório em vista frontal

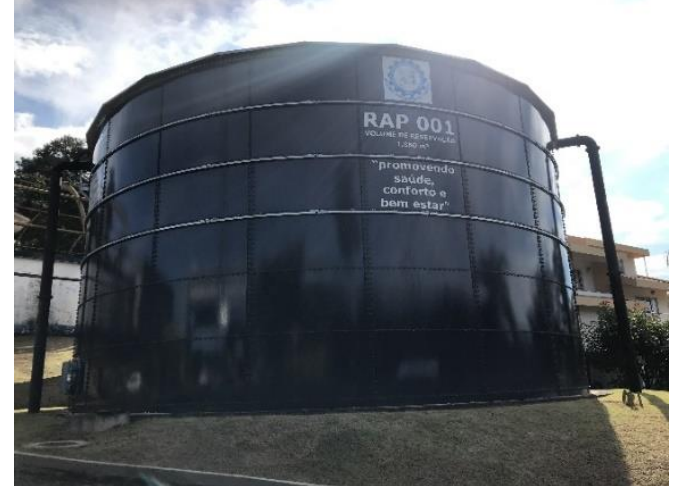

c) Placa de identificação do reservatório, que permite a rastreabilidade pelo fabricante Permastore

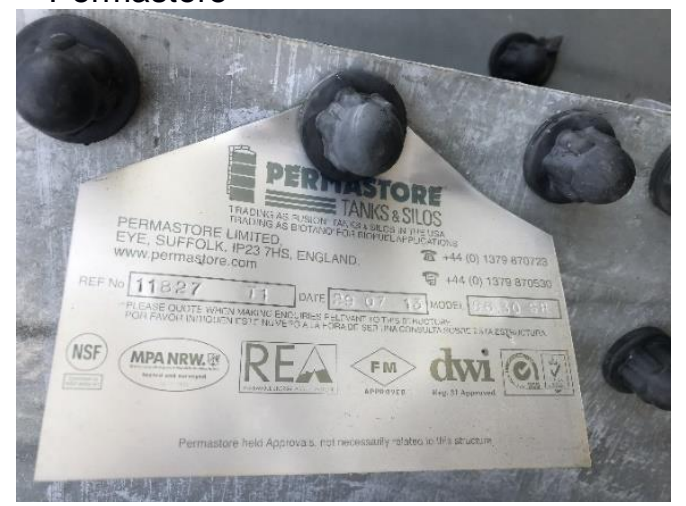

e) Quantidade de parafuso para fixação das chapas na vertical

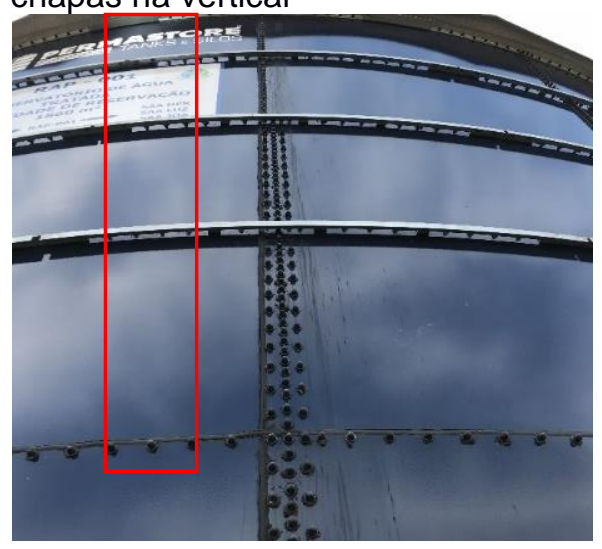

b) Reservatório em vista superior

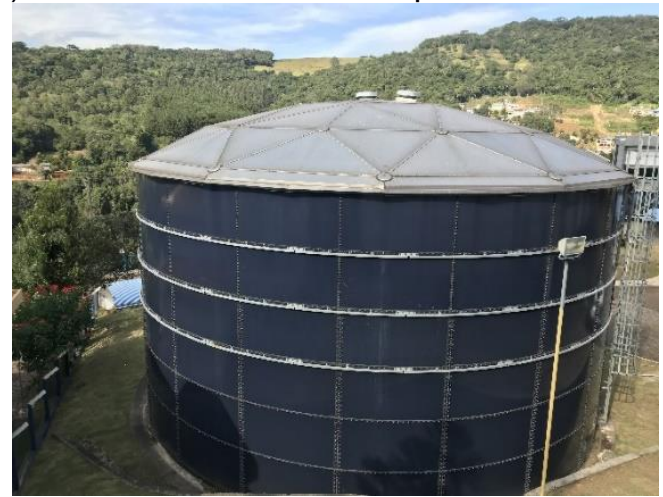

d) Identificação do controle de qualidade
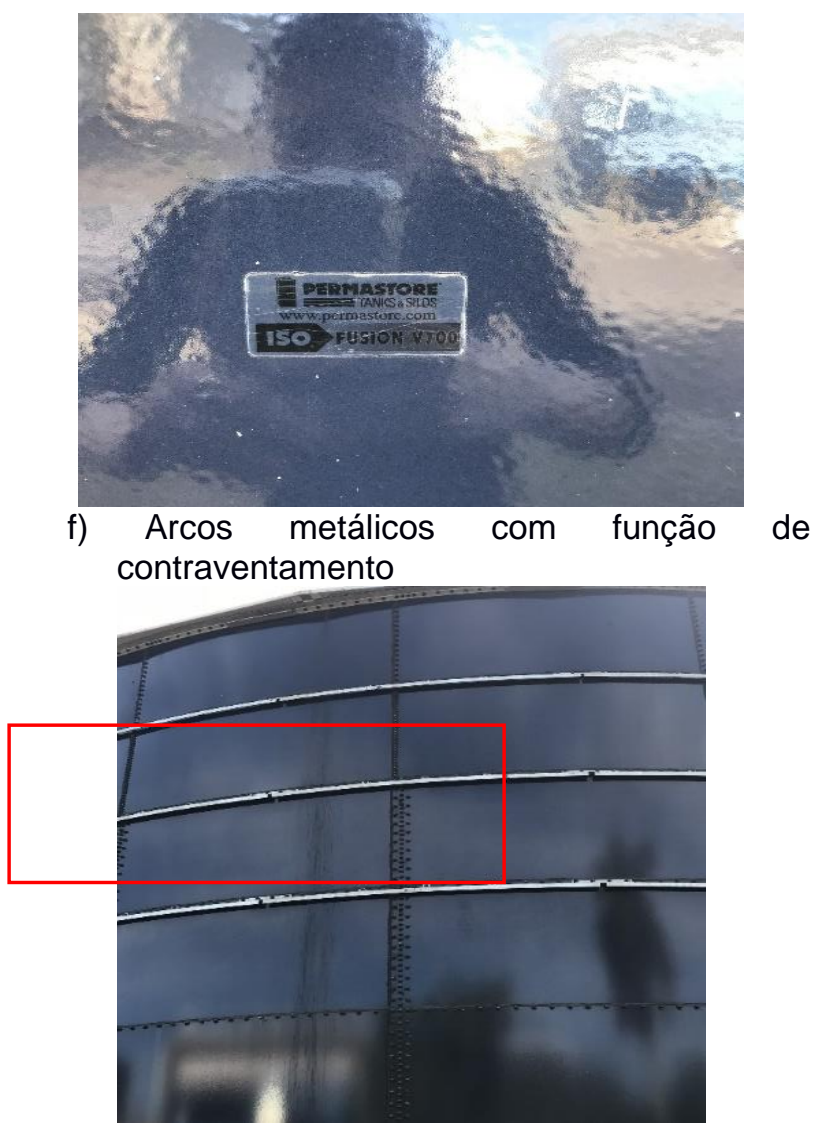
Figura 6 - Reservatório com placas em aço vitrificado - Detalhes

a) Encabeçamento dos parafusos

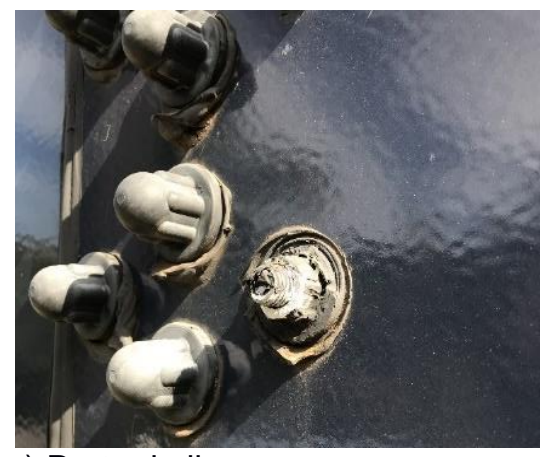

c) Porta de limpeza

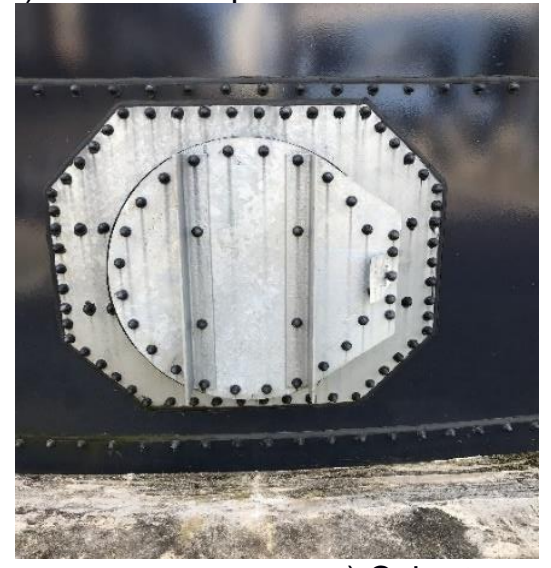

b) Detalhe da junção das placas e orifício para transporte

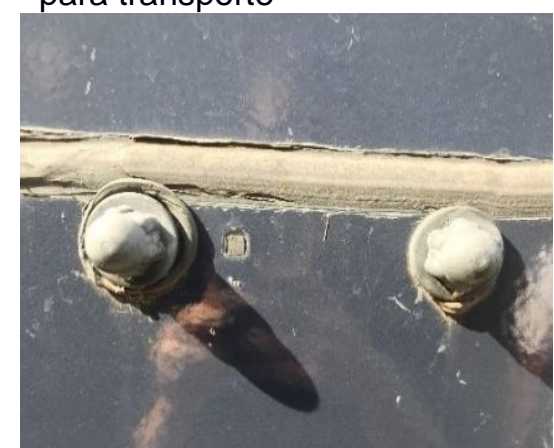

d) Escada tipo marinheiro

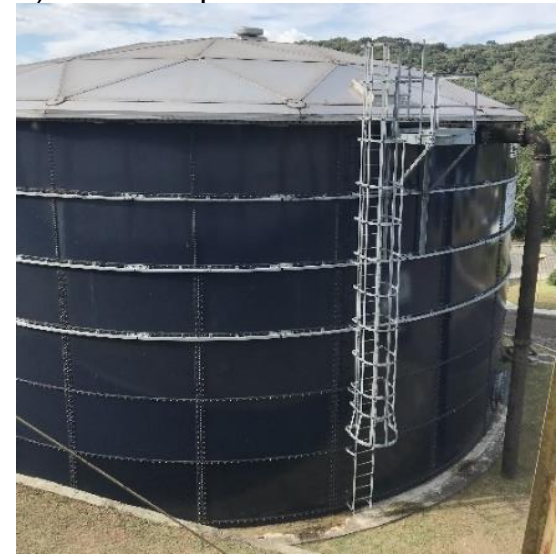

e) Cobertura em forma de cupula geodesica

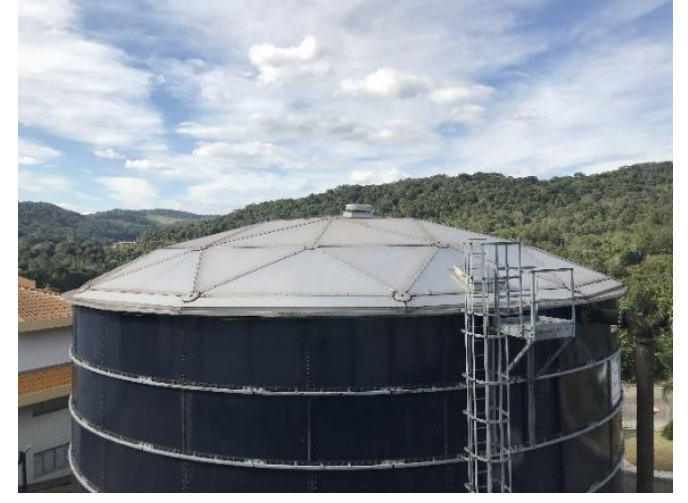

\subsubsection{Reservatório em concreto armado}

O reservatório em concreto armado (RAP001A) está instalado na ETA. Tem por finalidade armazenar água recém tratada e pronta para ser distribuída aos usuários do Simae. O volume útil de reservação é de $3.200 \mathrm{~m}^{3}$ de água (SIMAE, 2018Erro! Fonte de referência não encontrada.). Suas dimensões internas são: $20 \mathrm{~m} \times 40 \mathrm{~m} \times 4 \mathrm{~m}$ (L, W, Hútil). Do RAP001a água tratada é distribuída para as cidades de Herval d'Oeste, Joaçaba e Luzerna.

Conforme previsto no projeto original de engenharia o RAP001A (década de 90), foram executadas juntas de dilatação de $10 \mathrm{em} 10 \mathrm{~m}$ (). Para permitir a trabalhabilidade da 
estrutura e a estanqueidade do tanque, nestas juntas, foram utilizados perfis de PVC de alta densidade, conhecidos como juntas de dilatação tipo fugenband.

Figura 7 - Juntas de dilatação do reservatório de concreto armado do RAP001 do Simae Joaçaba

a) Localização na junta na parede

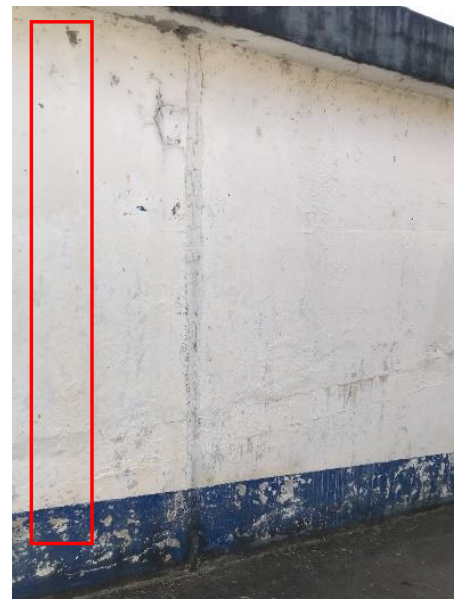

b) Parede longitudinal com descolamento do EPS e bolor

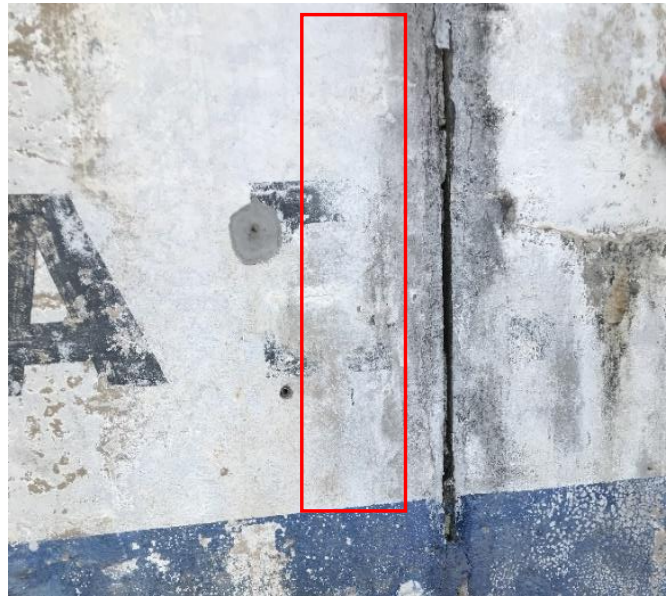

O reservatório RAP001A em concreto armado foi construído em 1997, e nos seus primeiros 20 anos, apresentou patologias no seu conjunto, comentadas a seguir.

Ocorre trabalhabilidade da estrutura na junta de dilatação e o preenchimento em EPS para fins estéticos, não resistiu e acabou se descolando (Figura 8). Ressalta-se que apesar do descolamento da parte em EPS, não há vazamento na junta, o que atesta o bom funcionamento das juntas de dilatação tipo fugenband. Não há registro de manutenção feita desde a construção nas juntas de dilatação. Surgem as manchas de bolor ocasionadas por infiltração de umidade.

Corroborando com resposta do Simae dada ao questionário, referente à manutenção e reparos, na Figura 9 , é possível observar um dos vazamentos do tanque de concreto. $O$ vazamento ocorreu em um ponto que é considerado o mais crítico em reservatórios de concreto, ou seja, na junção do piso com a parede. Este vazamento provocou o descolamento do revestimento (emboço).

Foram observadas, durante vistoria in loco, patologias no reservatório em concreto armado, como bolor, eflorescência, mofo, rachaduras, trincas e fissuras em todas as direções.

$\mathrm{Na}$ a) a) a patologia mais evidente é a fissura vertical, em certos trechos a $45^{\circ} \mathrm{e}$ em outros quase horizontal. Constata-se a criação de bolor e eflorescência e inúmeras microfissuras. O ponto de vazamento de água na parede lateral esquerda do reservatório é visto em 10 b) e apresenta rachadura vertical, bolor e mofo. A estrutura do reservatório continuou em movimentação (10 c), abrindo novamente rachaduras em pontos onde já haviam sido executados reforços estruturais, permitindo vazamentos de água. A patologia de eflorescência $(10 \mathrm{~d})$, está contaminando praticamente toda a parede frontal do reservatório, o que põe em dúvida a impermeabilidade das paredes. 
Figura 9 - Local de vazamento do reservatório em concreto armado RAP001 do Simae Joaçaba

a) Ponto de vazamento

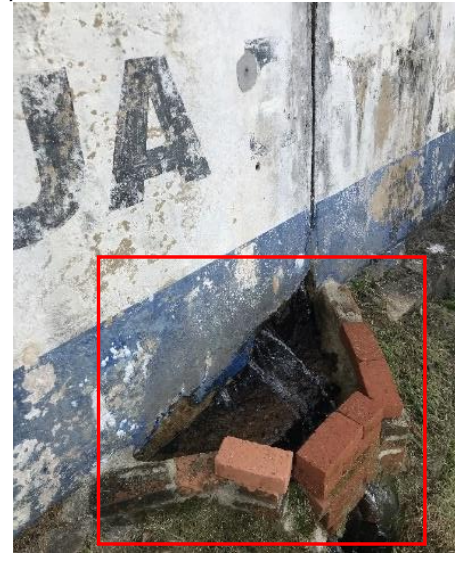

b) Detalhe

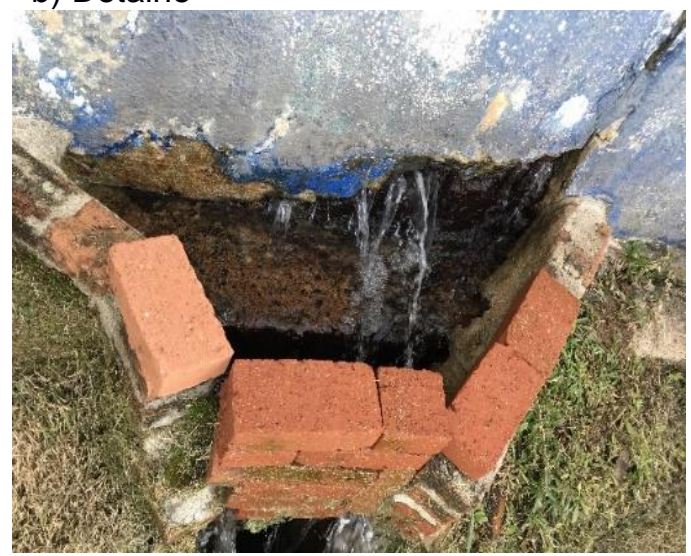

Figura 10 - Fissuras e patologias no reservatório em concreto armado RAP001 do Simae Joaçaba

a) Parede frontal com fissura, bolor e eflorescência

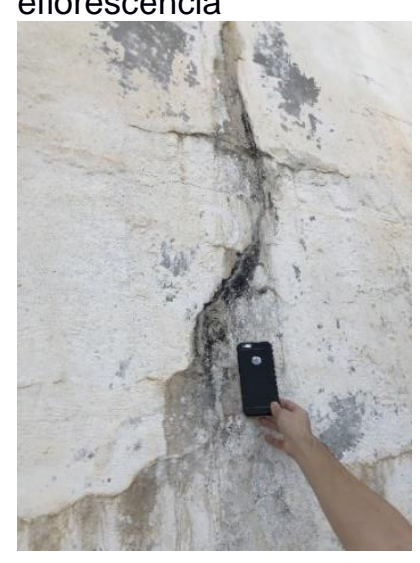

b) Patologias na parede lateral esquerda

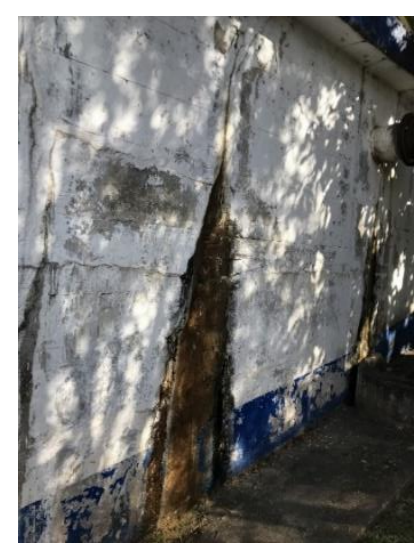

c) Rachadura na parede frontal

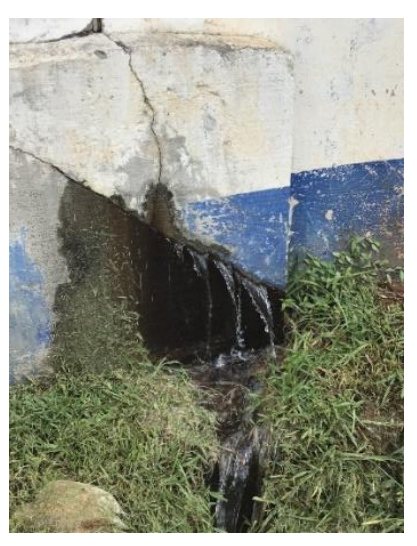

d) Eflorescência, manchas distribuídas ao longo da parede

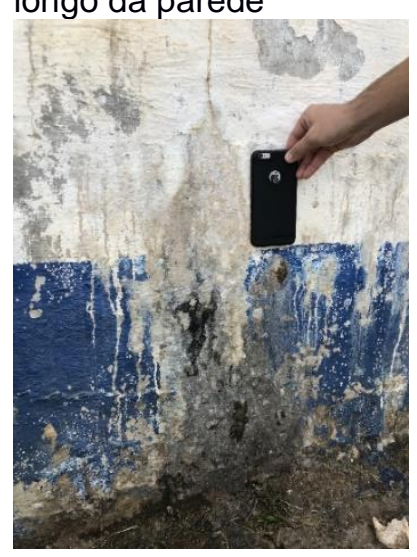

A perda de água tratada nas rachaduras está estimada em torno de $2 \%$. A relevância deste valor está no fato de ser água que já passou pelo processo de tratamento e a perda ser debitada para o próprio Simae. Evitar perdas é a principal vantagem do uso dos reservatórios em aço vitrificado pela estanqueidade assegurada.

\subsection{Analise das respostas ao questionário aplicado às empresas}

O questionário, enviado em meio digital, foi respondido pelas empresas denominadas Empresa 01 - "E1" e Empresa "E2" como segue:

a) Quais os diferentes tipos de reservatórios de armazenamento de água potável fabricados pela empresa? Respostas: concreto armado (E2); chapas de aço vitrificado, chapas metálicas com pintura epóxi, chapas metálicas, outros: reservatório galvanizados (E1). 
b) Como é realizado o transporte dos materiais da indústria até o local da obra? Respostas: Transporte marítimo internacional e terrestre rodoviário nacional (E1); os equipamentos são transportados por veículo próprio (E2).

c) Qual a resistência que esse material deve apresentar e como é verificada a adequação? Respostas: conforme Norma API-650, AWWA d-103, EUROCODE (E1); garantia de obra: seguindo determinações da ABNT e Código Civil Brasileiro e código do consumidor (E2).

d) Qual o tipo de mão de obra necessária para a construção? A empresa disponibiliza mão de obra especializada? Respostas: todos produtos são pré-fabricados. Não há nenhum tipo de usinagem em campo. Apenas montagem com juntas parafusadas. Portanto, a mão de obra utilizada são montadores especializados em trabalho em altura (E1); Sim (E2).

e) Qual o tempo de instalação de um reservatório por completo? Se possível anexar um cronograma de implantação de um reservatório. Respostas: depende muito do tamanho do reservatório. Nosso produto padrão é reservatório com $1.000 \mathrm{~m}^{3}$ de volume. Média de 40 dias para montagem (E1); depende do diâmetro e altura (E2).

f) Em relação ao preço, o sistema apresenta competitividade com outros? Se possível anexar um orçamento de um reservatório. Respostas: acreditamos que temos o melhor preço do mercado. Porém por tratar-se de um produto onde $90 \%$ da demanda é solicitado por empresas públicas, enfrentamos o lobby de outras empresas que dificultam a venda por sermos uma empresa $100 \%$ idônea. Reservatório com painéis em aço com revestimento em pintura epóxi, de $1.000 \mathrm{~m}^{3}$, varia em torno de $R \$$ $700.000,00$. Reservatórios em aço com revestimento vitrificado, de $1.100 \mathrm{~m}^{3}$, varia em torno de $\mathrm{R} \$ 1.350 .000,00$. Reservatórios com revestimento galvanizado nas placas, de $330 \mathrm{~m}^{3}$, varia em torno de $\mathrm{R} \$ 150.000,00$ (E1); Sim, fazemos no Brasil inteiro (E2).

A Tabela 3 mostra os resultados do questionário aplicado para as empresas fabricantes/fornecedoras de reservatórios em aço vitrificado, nos aspectos de fabricação, transportes, atendimento as normas técnicas e custo por volume armazenado, expresso em metros cúbicos.

Os reservatórios metálicos em placas de aço vitrificado tem o custo superior aos tradicionais em concreto armado (Tabela 3), por ser tecnologia importada, ter rígido controle de qualidade na fabricação das placas, seguir normas internacionais, necessitar de mão de obra especializada para realizar a montagem das placas em aço vitrificado. 
Tabela 3 - Reservatórios de água potável (fabricação, transporte, montagem e custo por volume) por empresa fabricante

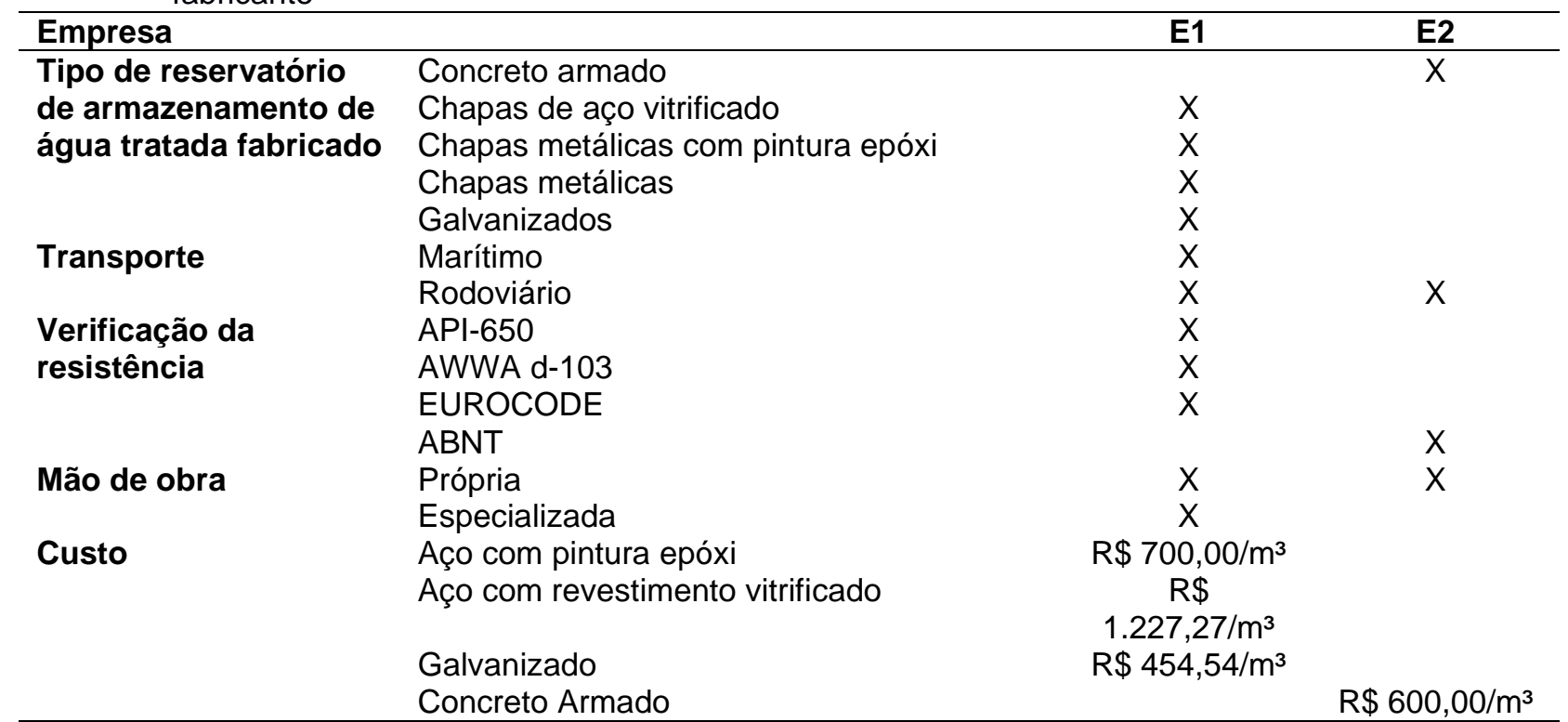

\section{CONCLUSÕES}

Foram visitados reservatórios de água potável, construídos com distintos materiais, concreto armado e aço vitrificado. O principal objetivo foi conhecer o uso das chapas em aço vitrificado utilizadas para construção de reservatórios, tecnologia recente no Brasil (2006) com o pioneirismo do Simae Joaçaba.

A documentação bibliográfica e a constatação pelo questionário respondido por usuários demontram que 0 material une as vantagens estruturais de resistência e flexibilidade do aço com a proteção de um material inerte como o vidro protegendo o tanque das intempéries e da corrosão.

A principal vantagem do uso de placas de aço vitrificado para construção de reservatórios de água potável está no rígido controle de qualidade na fabricação das placas, seguindo normas internacionais. $O$ sistema de montagem permite uma execução rápida, uma menor mobilização de mão de obra e um canteiro de obras organizado e ocupando espaço reduzido.

A principal desvantagem é a não fabricação das placas metálicas em aço com revestimento vitrificado no Brasil, necessitando da importação. Há pouca oferta do produto no mercado e o preço final dos reservatórios em chapas de aço vitrificado para armazenamento de água potável fica com valor superior aos tradicionalmente usados pelas companhias de saneamento.

Há necessidade de mão de obra especializada para montagem das placas de aço vitrificado que compõe as paredes dos reservatórios com esta tecnologia, diferentemente do que acontece com os reservatórios tradicionais totalmente em concreto armado, que podem ser construídos com mão de obra local, não especializada.

A atual realidade do Simae Joaçaba corrobora a opção de construção de reservatórios com o uso da tecnologia de paredes em aço vitrificado, como tem sido os sete 
reservatórios implantados a partir do ano 2007. No início do ano de 2018, foi realizada a compra do oitavo reservatório com uso desta tecnologia.

O uso de chapas de aço vitrificado para armazenamento de água tratada garante que não haja corrosão interna ou externa nas paredes, diminuindo significativamente despesas com manutenção, eliminando perdas de água do reservatório, dando maior segurança e economia ao sistema.

\section{REFERÊNCIAS}

ALMEIDA, Diogo Fonseca Carbonari de. Controle e Redução de Perdas Reais em Sistemas de Abastecimento de Água. Disciplina de PHD 2537 - Águas em Ambientes Urbanos.

Departamento de Engenharia Hidráulica e Sanitária. Escola Politécnica da Universidade de São Paulo. 2006. Disponível em: www.pha.poli.usp.br/LeArq.aspx?id arq=1408. Acesso em 11 Jun. 2019.

ABES. Associação Brasileira de Engenharia Sanitária e Ambiental. Perdas em sistemas de abastecimento de água: diagnóstico, potencial de ganhos com sua redução e propostas de medidas para o efetivo combate. São Paulo, 2013. Disponível em: http://www.abessp.org.br/arquivos/perdas.pdf. Acesso em: 21 fev. 2018.

BACARIN, Levi et al. A experiência da implantação de reservatórios metálicos parafusados na UN SUL/Sabesp. São Paulo, 2017. Disponível em: https://www.tratamentodeágua.com.br/wpcontent/uploads/2017/10/l-126.pdf. Acesso em: 12 mar. 2018.

BAUDY, Thiago Augusto. METALTEC Engenharia Ltda. Contribuição pessoal. Florianópolis, 2018.

BORGES, Micheline Gonçalves. Manifestações patológicas incidentes em reservatórios de água elevados executados em concreto armado. 2008. 111 p. Monografia - Universidade Estadual de Feira de Santana, Bahia, 2008. Disponível em:

http://civil.uefs.br/DOCUMENTOS/MICHELINE\%20GON\%C3\%87ALVES\%20BORGES.pdf. Acesso em: 7 maio 2018.

DAEB. Departamento de Água, Arroios e Esgoto de Bagé - RS. Inauguração do novo reservatório está entre as comemorações dos 50 anos do Daeb. Disponível em:

http://daeb.com.br/noticiasView/8300 Inauguracao-do-novo-reservatorio-esta-entre-ascomemoracoes-dos-50-anos-do-Daeb.html. 26/02/2019. Acesso em 11 Jun. 2019.

EUROTANKS. Reservatórios em aço vitrificado parafusado. São Paulo, 2014. Disponível em: http://www.eurotanks.com.br/wp-content/uploads/2014/09/eurotanks.pdf. Acesso em: 15 mar. 2018.

MEDEIROS FILHO, Carlos Fernandes de. Abastecimento de Água. Reservatórios de Água. Universidade Federal de Campina Grande. UFCG. p. 122. Disponível em: www.margarita.dea.unir.br > uploads > arquivos > Apostilha Abast de A.... Acesso em: 28 Out. 2019.

OLIVEIRA, Gesner; MARCATO, Fernando S.; SCAZUFCA, Pedro; PIRES, Rodrigo Cintra. Perdas de Água 2018 (SNIS 2016): desafios para disponibilidade hídrica e avanço da eficiência do saneamento básico. São Paulo, 2018. Disponível em:

www.tratabrasil.org.br/images/estudos/itb/perdas-2018/estudo-completo.pdf. Acesso em: 11 Jun. 2019. 
SIMAE. Serviço Intermunicipal de Água e Esgoto. Acervo fotográfico e documental. Joaçaba, 2018.

TARGET. A tecnologia dos tanques de aços parafusados vitrificados. São Paulo, 2015. Disponível em: https://www.target.com.br/produtos/materias-tecnicas/2015/05/06/3665/atecnologia-dos-tanques-de-acos-parafusados-vitrificados. Acesso em: 16 mar. 2018.

TECH TANK. Secuencia de instalación, tanque de $25.000 \mathrm{~m}^{3}$, Barranquilla, Colômbia, $\mathbf{5 7 m} \mathbf{x}$ 14m. 2016.

TORRES, A. S. DA SILVA, V. M. B. PALIGA, C.M. Análise das manifestações patológicas em reservatórios elevados na cidade de Pelotas/RS. REEC - Revista Eletrônica de Engenharia Civil, v. 12, n. 1, 2016. Disponível em: https://www.revistas.ufg.br/reec/article/view/37740. Acesso em: 28 out. 2019. https://doi.org/10.5216/reec.v12i1.37740 